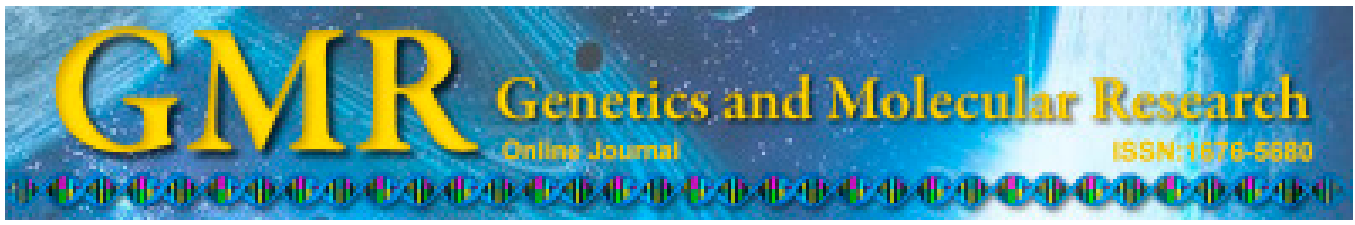

\title{
Genomic cloning, expression, and single nucleotide polymorphism association analysis of the insulin-like androgenic gland hormone gene in the oriental river prawn (Macrobrachium nipponense)
}

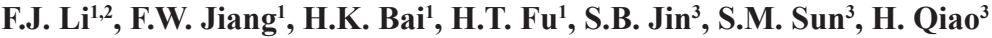 \\ and W.Y. Zhang ${ }^{3}$

\begin{abstract}
${ }^{1}$ Wuxi Fisheries College, Nanjing Agricultural University, Wuxi, China ${ }^{2}$ Weifang University of Science and Technology, Shouguang, Shandong, China ${ }^{3}$ Key Laboratory of Freshwater Fisheries and Germplasm Resources Utilization, Ministry of Agriculture, Freshwater Fisheries Research Center,
\end{abstract} \\ Chinese Academy of Fishery Sciences, Wuxi, China
}

Corresponding author: H.T. Fu

E-mail: fuht@ffrc.cn

Genet. Mol. Res. 14 (2): 5910-5921 (2015)

Received July 25, 2014

Accepted January 21, 2015

Published June 1, 2015

DOI http://dx.doi.org/10.4238/2015.June.1.8

\begin{abstract}
Increasing evidence suggests that the insulin-like androgenic gland hormone $(I A G)$ gene plays an important role in male sexual differentiation, metabolism, and growth in crustaceans. In the present study, we isolated the full-length genome sequence of $I A G$ by genome walking based on the cDNA sequence in Macrobrachium nipponense. Four novel single nucleotide polymorphisms (SNPs) were studied, including $509 \mathrm{G}>\mathrm{T}, 529 \mathrm{G}>\mathrm{T}, 590 \mathrm{~A}>\mathrm{T}$ in intron 1 , and $2226 \mathrm{~A}>\mathrm{G}$ in intron 2 . The association of genetic variation with growth traits [body length (BL) and body weight (BW)] was analyzed. Individuals with GG geno-
\end{abstract}


type at locus $2226 \mathrm{~A}>\mathrm{G}$ maintained higher mean $\mathrm{BL}(\mathrm{P}<0.01)$ and $\mathrm{BW}$ $(\mathrm{P}<0.05)$ than AA and GA individuals. These results suggest that $I A G$ SNPs may be useful molecular markers for selecting growth traits in M. nipponense.

Key words: Oriental river prawn; $I A G$ gene; Growth trait; Single nucleotide polymorphism

\section{INTRODUCTION}

The oriental river prawn Macrobrachium nipponense (Crustacea; Decapoda; Palaemonidae) is an important commercial prawn species. It is widely distributed in freshwater and low-salinity estuarine regions in China and other Asian countries (Cai and Shokita, 2006; Ventura et al., 2009; Zhang et al., 2011; Hongtuo er al., 2012). It is known that the males of many Macrobrachium species grow faster and gain more weight at harvest time than females, making male prawns more economically beneficial.

The insulin-like androgenic gland hormone $(I A G)$ gene plays an important role in both male sexual differentiation and growth in crustaceans (Rosen et al., 2010). IAG is secreted by the androgenic gland, which is an endocrine organ unique to males (Ventura et al., 2011). The cDNA sequence of $I A G$ has been cloned in several commercially important crustaceans (Manor et al., 2007; Sroyraya et al., 2010; Mareddy et al., 2011; Zhang et al., 2011; Chang et al., 2012; Ma et al., 2013). However, the distribution of the $I A G$ gene in the tissues of crustaceans differs. In the majority of crustaceans, the $I A G$ gene is exclusively transcribed in the androgenic gland. However, transcripts are also found in the hepatopancreas in Callinectes sapidus (Chung et al., 2011) and Fenneropenaeus chinensis (Li et al., 2012). In vivo silencing of the IAG gene in Macrobrachium rosenbergii, by injecting the prawns with $M r-I A G$ double-stranded RNA, temporarily prevented the regeneration of male secondary sexual characteristics, accompanied by a lag in molt and a reduction in growth parameters. The reduced growth of $M r-I A G$-silenced individuals implied that $M r-I A G$ may act as a growth regulator (Ventura et al., 2009). Further study has shown that the $I A G$ gene is closely related to metabolism in M. rosenbergii (Ventura et al., 2012). $I A G$ may, thus, represent an excellent positional and functional candidate gene for growth traits in crustaceans.

Growth traits are economically important factors in M. nipponense breeding, especially in males. Variations in growth traits have been attributed to different factors, including genetic factors (Wang et al., 2012). Single nucleotide polymorphisms (SNPs) have been widely used as an important molecular marker associated with traits (Du et al., 2012; Liu et al., 2012; Fu et al., 2013). However, no SNPs associated with growth traits have yet been identified in M. nipponense.

The purpose of this study was to isolate the full-length genome sequence of the $M$. nipponense IAG gene by genome walking and to detect SNPs in the $I A G$ gene. We further investigated the association of the SNPs with growth traits, with a view to identifying candidate markers related to growth traits. Owing to inconsistent reports about the tissue distribution of the $I A G$ gene, we investigated the expression level of the $I A G$ gene in different tissues of $M$. nipponense. 


\section{MATERIAL AND METHODS}

\section{Experimental materials}

Healthy adult oriental river prawns were obtained from Tai Lake in Wuxi, China $\left(120^{\circ} 13^{\prime} 44^{\prime \prime} \mathrm{E}, 31^{\circ} 28^{\prime} 22^{\prime \prime} \mathrm{N}\right)$. All the samples were transferred to laboratory breeding conditions and maintained in a $500 \mathrm{~L}$ tank with aerated freshwater for $72 \mathrm{~h}$ before tissue collection. Samples from 10 different tissues (eyestalk, heart, hepatopancreas, androgenic gland, gill, muscle, testis, sperm duct, brain, and nerve cord) were collected and immediately dipped into liquid nitrogen and stored at $-80^{\circ} \mathrm{C}$. Males $(\mathrm{N}=72)$ used for SNP analysis were from the same family. Body length (BL) and body weight (BW) were recorded for each prawn for association analysis.

\section{Genomic DNA isolation, cDNA synthesis, and bioinformatic analysis}

Genomic DNA was isolated using the DNA extraction kit (TaKaRa, Japan) according to the manufacturer protocol. Total RNA was extracted from the tissues using RNAiso Plus reagent (TaKaRa, Japan). Total RNA samples were reverse transcribed using AMV reverse transcriptase (TaKaRa) according to the manufacturer protocol, and the reverse transcription (RT)-reaction mixture was used as a template for further analysis. The full-length genome sequence was cloned using a Genome Walker Kit (Clontech, USA), according to the manufacturer protocol. All primers were designed according to the cDNA sequence of M. nipponense (GenBank: JX962354).

The Clustal W software (http://www.ebi.ac.uk/Tools/msa/clustalw2/) was used for alignment of multiple sequences. The promoter was predicted using NNPP version 2.2 (http://www.fruitfly.org/seq tools/promoter.html), and the CpG island was predicted using MethPrimer-Design Primers for Methylation PCRs (http://www.urogene.org/methprimer/). Transcription factor-binding sites in the promoter sequence of the $I A G$ gene were predicted using TFSEARCH (http://www.cbrc.jp/htbin/nph-tfsearch).

\section{mRNA expression analysis}

$I A G$ mRNA expression in various adult tissues was measured by SYBR Green realtime quantitative RT-PCR (qRT-PCR) analysis in a CFX96TM Real-Time System (Bio-Rad, USA). Gene-specific primers (Forward primer: ACCCAGGACCCACCTACATTT; Reverse primer: GCATCTTGTTCGCTTCTCTC) were used to amplify the $I A G$ transcript. $\beta$-actin primers (Forward primer: GACGGTCAGGTCATCACCA; Reverse primer: ACGTCGCACT TCATGATGGA) were used to amplify the $\beta$-actin fragments, which were used as an internal control. Amplifications were performed on a 96-well plate with a $20 \mu \mathrm{L}$ reaction volume containing $10 \mu \mathrm{L} 2 \mathrm{X}$ SYBR Green Premix Ex Taq (TaKaRa), $0.4 \mu \mathrm{L}$ of each primer $(2 \mu \mathrm{M})$, $2 \mu \mathrm{L}$ template, and 7.2 $\mu \mathrm{L}$ PCR-grade water. The thermal profile for SYBR Green qRT-PCR was $95^{\circ} \mathrm{C}$ for $10 \mathrm{~min}$ followed by 40 cycles of $95^{\circ} \mathrm{C}$ for $15 \mathrm{~s}$ and $60^{\circ} \mathrm{C}$ for $1 \mathrm{~min}$. Diethylpyrocarbonate-water for template placement was used as a negative control. A relative standard curve was constructed using 10-fold serially-diluted cDNA. Each sample was run in triplicate, along with the internal control gene. To ensure that only one PCR product was amplified and detected, dissociation curve analysis of the amplification products was performed at the end of 
each PCR reaction. The relative copy numbers of $I A G$ mRNAs were calculated according to the $2^{-\Delta \Delta C}$ comparative CT method (Livak and Schmittgen, 2001).

\section{SNP primer design and PCR amplification}

Comparison of 10 individual DNA sequences using the Clustal W software indicated the same site was identified as a SNP site if the ratio of different bases was greater than $1 / 4$. Based on the genome sequence of the $I A G$ gene (exon 1, intron 1, exon 2, intron 2), four pairs of primers were designed using the Primer 3.0 software (Table 1 ). The $25-\mu \mathrm{L}$ reaction mixture contained 50 ng genomic DNA, $0.5 \mu \mathrm{M}$ of each primer, $1 \mathrm{X}$ buffer (including $1.5 \mathrm{mM} \mathrm{MgCl}$ ), $200 \mu \mathrm{M}$ dNTPs, and $0.5 \mathrm{U}$ Taq DNA Polymerase (TaKaRa). The cycling protocol was $10 \mathrm{~min}$ at $94^{\circ} \mathrm{C}, 30$ cycles at $94^{\circ} \mathrm{C}$ for $30 \mathrm{~s}$, annealing at melting temperature (Tm) for $30 \mathrm{~s}$, depending on the primer (Table 1 ), $72^{\circ} \mathrm{C}$ for $40 \mathrm{~s}$, with a final extension at $72^{\circ} \mathrm{C}$ for $10 \mathrm{~min}$. PCR products were electrophoresed on a $1.5 \%$ agarose gel.

\section{Table 1. Primers used for genotyping the four SNPs in the $I A G$ gene.}

\begin{tabular}{|c|c|c|c|c|}
\hline Locus & Primer sequence $\left(5^{\prime}-3^{\prime}\right)$ & $\operatorname{Tm}\left({ }^{\circ} \mathrm{C}\right)$ & Position & Enzyme \\
\hline $509 \mathrm{G}>\mathrm{T}$ & $\begin{array}{l}\text { GATCATACTGCATTGGGTTCACAG } \\
\text { GTTATGGGGTTATTGCCGTCAG }\end{array}$ & 60 & Intron 1 & EcoRV \\
\hline $529 \mathrm{G}>\mathrm{T}$ & $\begin{array}{l}\text { TTACAGTGACCCCCATGAGGTGC } \\
\text { AATTCCAGCCACCCTTTTTGGTC }\end{array}$ & 55 & Intron 1 & $\operatorname{Taq} \mathrm{I}$ \\
\hline $590 \mathrm{~A}>\mathrm{T}$ & $\begin{array}{l}\text { GTCAGCTAGGACAAGGCAACATG } \\
\text { GACTTCATTCGCTTGACTTGTGG }\end{array}$ & 60 & Intron 1 & MboI \\
\hline $2226 \mathrm{~A}>\mathrm{G}$ & $\begin{array}{l}\text { AACCCAGGACCCACCTACATTTC } \\
\text { GTATAGTTGTCAGCAGATCGTC }\end{array}$ & 62 & Intron 2 & AsuII \\
\hline
\end{tabular}

$\mathrm{Tm}=$ melting temperature.

\section{SNP genotyping}

Four SNP loci detected in the $I A G$ gene were genotyped using PCR-restriction fragment length polymorphism (RFLP). The PCR products were digested with restriction enzymes for $5 \mathrm{~h}$ at $37^{\circ} \mathrm{C}$ in a total volume of $16 \mu \mathrm{L}$ containing $1 \mathrm{X}$ buffer, $5 \mathrm{U}$ enzyme, and $8 \mu \mathrm{L} \mathrm{PCR}$ products. The digested PCR products were separated by $2.0 \%$ agarose gel electrophoresis and observed with a gel-imaging system. Each genotype was defined according to its band pattern by analyzing nucleotide changes in the PCR products of different RFLP types corresponding to each genotype.

\section{Statistical analysis}

The allelic and genotypic frequencies, genetic indices of observed heterozygosity $\left(H_{\mathrm{O}}\right)$, expected heterozygosity $\left(H_{\mathrm{E}}\right)$, effective number of alleles $\left(N_{\mathrm{E}}\right)$, and polymorphism information contents (PIC) were calculated using the POPGENE software (v3.2). The HardyWeinberg equilibrium of the mutations was determined by $\chi^{2}$ tests. Correlations between $I A G$ genotypes and growth traits (BL, BW) were analyzed using the generalized linear model procedure with the SPSS 21 software, according to the following statistical linear model:

$$
\mathrm{Y}_{\mathrm{ij}}=\mu+\mathrm{G}_{\mathrm{i}}+\mathrm{E}_{\mathrm{ij}}
$$


where, $Y_{i j}$ is the observed value, $\mu$ is the overall population mean, $G_{i}$ is the effect of the ith genotype, and $\mathrm{E}_{\mathrm{ij}}$ is the random error. Linkage disequilibrium (LD) and haplotype analyses were performed using online software (http://analysis.bio-X.cn/myAnalysis.php) (Yong and Lin, 2005; Li et al., 2009). Specific parameters were as follows: "Pair-loci $\mathrm{D}^{\prime} / \mathrm{r}^{2}$ value" and "Haplotype analysis" were selected; Number of sites $=4$; Selected sites for haplotype analysis $=1,1,1,1$; Default value is 0.03 .

\section{RESULTS}

\section{Genomic DNA cloning of the $M$. nipponense IAG gene}

The genomic DNA (GenBank: KF811212) consisted of a promoter (1600 bp), exon 1 (27 bp), intron 1 (1795 bp), exon 2 (172 bp), intron 2 (615 bp), exon 3 (113 bp), intron 3 (1193 bp), exon 4 (183 bp), intron 4 (1448 bp), and exon 5 (33 bp) (Figure 1). The exonintron splice junctions in $I A G$ followed the GT-AG pattern seen in many eukaryotic genes. Potential transcription factor-binding sites were identified using the TFSEARCH database. These included HSF, GATA-1, GATA-2, and SRY. The promoter element TATA box and CAAT box were found in this sequence. The TATA box sequence was located approximate 30 bp upstream of the transcription start site. A CpG island was located between the TATA box and the first exon region. Similar sequences were also found in the $5^{\prime}$ flanking sequences of F. chinensis (Li et al., 2012).

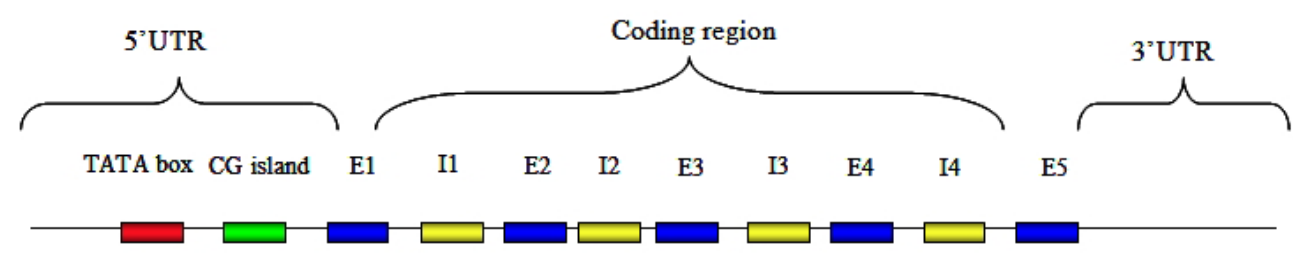

Figure. 1. Structure of the $I A G$ gene in Macrobrachium nipponense. Red box denotes TATA box; green box denotes $\mathrm{CpG}$ island; blue box denotes exon (exon $1=27 \mathrm{bp}$; exon $2=172 \mathrm{bp}$; exon $3=113 \mathrm{bp}$; exon $4=183 \mathrm{bp}$; exon $5=33$ bp); yellow box denotes intron (intron $1=1795 \mathrm{bp}$; intron $2=615 \mathrm{bp}$; intron3 = $1193 \mathrm{bp}$; intron4 = $1448 \mathrm{bp}$ ); $5^{\prime} \mathrm{UTR}$ denotes 5'untranslated region; 3'UTR denotes 3'untranslated region.

\section{mRNA expression analysis}

The tissue distribution of the $I A G$ gene was determined using qRT-PCR. The $I A G$ gene was present at high levels in the androgenic gland and at low levels in the hepatopancreas (about $1 \%$ of that in the androgenic gland). No expression was detected in other tissues, including the eyestalk, heart, gill, muscle, testis, sperm duct, brain, or nerve cord (Figure 2).

\section{SNP identification}

Four SNPs were detected. Sequencing analysis revealed that the mutations occurred at positions $509 \mathrm{G}>\mathrm{T}, 529 \mathrm{G}>\mathrm{T}$, and $590 \mathrm{~A}>\mathrm{T}$ in intron 1 , and $2226 \mathrm{~A}>\mathrm{G}$ in intron 2 of the $I A G$ gene. PCR-RFLP was used to genotype the individuals. According to the sequence vari- 
ants, the PCR product could be digested with the EcoRV, TaqI, MboI, and AsuII restriction enzymes. Two possible genotypes were defined by two distinct banding patterns at locus 509G > T: TT (a fragment of $355 \mathrm{bp}$ ), and GT (168 and $187 \mathrm{bp}$ ). Three possible genotypes were defined by three distinct banding patterns at locus $529 \mathrm{G}>\mathrm{T}$ : TT (a fragment of $419 \mathrm{bp}$ ), GT (419, 221, and $198 \mathrm{bp})$ and GG (221 and $198 \mathrm{bp})$. Three possible genotypes were defined by three distinct banding patterns at locus $590 \mathrm{~A}>\mathrm{T}$ : TT (a fragment of $355 \mathrm{bp}$ ), AT (355, 124, and $231 \mathrm{bp}$ ), and AA (124 and $231 \mathrm{bp}$ ). Three possible genotypes were defined by three distinct banding patterns at locus $2226 \mathrm{~A}>\mathrm{G}$ : GG (a fragment of $576 \mathrm{bp}$ ), AG (576, 260, and $316 \mathrm{bp}$ ), and AA (260 and $316 \mathrm{bp})$.

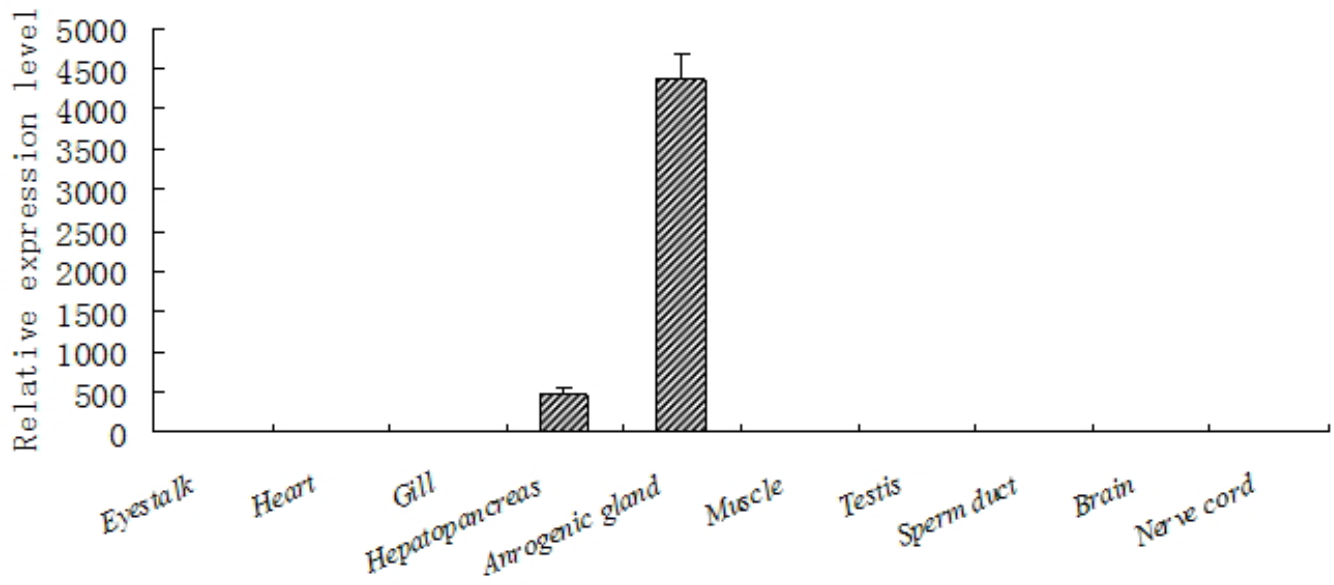

Figure. 2. Expression profiles of the $I A G$ gene in different tissues of Macrobrachium nipponense based on quantitative real-time PCR. The tissues included eyestalk, heart, hepatopancreas, androgenic gland, gill, muscle, testis, sperm duct, brain, and nerve cord. The IAG mRNA amount was normalized to the $\beta$-actin mRNA level. Data from quantitative real-time PCR are reported as means \pm SE (standard error).

\section{SNP diversity analysis and association with growth traits}

The genetic diversity of the family analyzed was evaluated by calculating the genetic indices $\left(H_{\mathrm{O}}, H_{\mathrm{E}}, N_{\mathrm{E}}\right.$ and PIC) for the four polymorphic loci (Table 2). $H_{\mathrm{E}}$ ranged from 0.3333 to 0.7639 , and $N_{\mathrm{E}}$ ranged from 1.7643 to 1.9369 at the four loci. According to the PIC classification (PIC $\leq 0.25$, low polymorphism; $0.25<$ PIC $<0.50$, intermediate polymorphism; PIC $\geq 0.50$, high polymorphism), $529 \mathrm{G}>\mathrm{T}$ and $590 \mathrm{~A}>\mathrm{T}$ loci were both highly polymorphic, while the $509 \mathrm{G}>\mathrm{T}$ locus was classified as showing low polymorphism, and the $2226 \mathrm{~A}>\mathrm{G}$ locus belonged to the intermediate polymorphism category.

The associations of the four $I A G$ mutations in $M$. nipponense with growth traits represented by $\mathrm{BL}$ and $\mathrm{BW}$ were analyzed (Table 3 ). At locus $2226 \mathrm{~A}>\mathrm{G}$, prawns with the GG genotype had wider arthromeres $(\mathrm{P}<0.01)$ and heavier $\mathrm{BWs}$ than those with the AA and GA genotypes $(\mathrm{P}<0.05)$. There were no significant differences between genotypes at loci $509 \mathrm{G}>\mathrm{T}, 529 \mathrm{G}>\mathrm{T}$, and 590A $>\mathrm{T}(\mathrm{P}>0.05)$. 


\section{Analysis of LD and haplotypes}

Linkage disequilibrium between polymorphism pairs and haplotype structure analysis of the $I A G$ gene in $M$. nipponense populations are shown in Figure 3 and Table 4. The LD between the four SNPs was estimated (Figure 3.), which indicated that the $\mathrm{D}^{\prime}$ values ranged from 0.24 to 0.82 ; the $\mathrm{r}^{2}$ values were from 0.01 to 0.68 . The $\mathrm{D}^{\prime}$ and $\mathrm{r}^{2}$ values for the SNP pairs $509 \mathrm{G}>\mathrm{T}$ and $590 \mathrm{~A}>\mathrm{T}\left(\mathrm{D}^{\prime}=0.82, \mathrm{r}^{2}=0.68\right)$, and $509 \mathrm{G}>\mathrm{T}$ and $2226 \mathrm{~A}>\mathrm{G}$ $\left(\mathrm{D}^{\prime}=0.80, \mathrm{r}^{2}=0.54\right)$ were relatively higher than for the other pairs, which implied the SNP pairs $509 \mathrm{G}>\mathrm{T}$ and $590 \mathrm{~A}>\mathrm{T}$, and $509 \mathrm{G}>\mathrm{T}$ and $2226 \mathrm{~A}>\mathrm{G}$ were in strong linkage disequilibrium $(\mathrm{r} 2>0.33)$, and the other pairs exhibited weak $\mathrm{LD}\left(\mathrm{r}^{2}<0.33\right)$. The result of haplotype analysis of four SNPs showed that 11 different haplotypes were identified in these prawns (Table 4). The most common haplotypes were H1 (GGAA) and H5 (GTAG), occurring at a frequency of 34.54 and $47.41 \%$, respectively. H8 (TGAG) had the lowest haplotype frequency $(0.52 \%)$.

Table 2. Genotype and allele frequencies and genetic diversity parameters for $I A G$ in $M$. nipponense.

\begin{tabular}{|c|c|c|c|c|c|c|c|c|c|}
\hline \multirow{2}{*}{$\frac{\text { Locus }}{509 \mathrm{G}>\mathrm{T}}$} & \multicolumn{2}{|c|}{ Genotype n (\%) } & \multicolumn{2}{|c|}{ Allele frequency } & \multirow{2}{*}{$\frac{H_{\mathrm{O}}}{0.2361}$} & \multirow{2}{*}{$\frac{H_{\mathrm{E}}}{0.7639}$} & \multirow{2}{*}{$\frac{N_{\mathrm{E}}}{1.7643}$} & \multirow{2}{*}{$\begin{array}{c}\text { PIC } \\
0.2956\end{array}$} & \multirow{2}{*}{$\frac{\chi^{2} \text { (HWE) }}{26.92}$} \\
\hline & $\begin{array}{l}\text { TG } \\
\text { TT }\end{array}$ & $\begin{array}{r}110(76.39 \%) \\
34(23.61 \%)\end{array}$ & $\begin{array}{l}\mathrm{G} \\
\mathrm{T}\end{array}$ & $\begin{array}{l}38.19 \% \\
61.81 \%\end{array}$ & & & & & \\
\hline $529 \mathrm{G}>\mathrm{T}$ & $\begin{array}{l}\text { GG } \\
\text { TG }\end{array}$ & $\begin{array}{l}64(44.44 \%) \\
46(31.94 \%)\end{array}$ & $\begin{array}{l}\mathrm{G} \\
\mathrm{T}\end{array}$ & $\begin{array}{l}61.11 \% \\
38.89 \%\end{array}$ & 0.6667 & 0.3333 & 1.9253 & 0.5710 & 8.1592 \\
\hline & TT & $34(23.62 \%)$ & & & & & & & \\
\hline $590 \mathrm{~A}>\mathrm{T}$ & $\begin{array}{l}\text { AA } \\
\text { TA } \\
\text { TT }\end{array}$ & $\begin{array}{l}22(15.28 \%) \\
66(45.83 \%) \\
56(38.89 \%)\end{array}$ & $\begin{array}{l}\mathrm{A} \\
\mathrm{T}\end{array}$ & $\begin{array}{l}38.19 \% \\
61.81 \%\end{array}$ & 0.4583 & 0.5417 & 1.8944 & 0.5349 & 0.09 \\
\hline $2226 \mathrm{~A}>\mathrm{G}$ & $\begin{array}{l}\text { AA } \\
\text { GA } \\
\text { GG }\end{array}$ & $\begin{array}{l}42(29.17 \%) \\
86(59.72 \%) \\
16(11.11 \%)\end{array}$ & $\begin{array}{l}A \\
G\end{array}$ & $\begin{array}{l}59.03 \% \\
40.97 \%\end{array}$ & 0.4028 & 0.5972 & 1.9369 & 0.4743 & 3.7368 \\
\hline
\end{tabular}

$H_{\mathrm{O}}=$ gene homozygosity; $H_{\mathrm{E}}=$ gene heterozygosity; $N_{\mathrm{E}}=$ effective allele numbers; $\mathrm{PIC}=$ polymorphism information content; $\chi^{2}=$ Hardy-Weinberg equilibrium $\chi^{2}$ value.

Table 3. Association of $I A G$ SNPs with growth traits in M. nipponense.

\begin{tabular}{|c|c|c|c|c|c|}
\hline \multirow{2}{*}{$\begin{array}{l}\text { Locus } \\
509 \mathrm{G}>\mathrm{T}\end{array}$} & \multirow[t]{2}{*}{ Trait } & \multicolumn{3}{|c|}{ Genotype (means $\pm \mathrm{SE}$ ) } & \multirow[t]{2}{*}{$P$ value } \\
\hline & & $\mathrm{TG}(\mathrm{N}=54)$ & $\mathrm{TT}(\mathrm{N}=18)$ & & \\
\hline & $\mathrm{BL}(\mathrm{cm})$ & $6.1074 \pm 0.08$ & $5.8722 \pm 0.07$ & - & 0.166 \\
\hline & BW (g) & $5.1148 \pm 0.21$ & $4.5167 \pm 0.30$ & - & 0.158 \\
\hline \multirow{3}{*}{$529 \mathrm{G}>\mathrm{T}$} & & $\mathrm{GG}(\mathrm{N}=32)$ & $\mathrm{TG}(\mathrm{N}=23)$ & $\mathrm{TT}(\mathrm{N}=17)$ & \\
\hline & $\mathrm{BL}(\mathrm{cm})$ & $6.1188 \pm 0.10$ & $5.9696 \pm 0.13$ & $6.0235 \pm 0.16$ & 0.604 \\
\hline & $\mathrm{BW}(\mathrm{g})$ & $4.6696 \pm 0.33$ & $5.1594 \pm 0.25$ & $5.0000 \pm 0.18$ & 0.518 \\
\hline \multirow[t]{3}{*}{$590 \mathrm{~A}>\mathrm{T}$} & & $\mathrm{AA}(\mathrm{N}=29)$ & $\mathrm{TA}(\mathrm{N}=10)$ & $\mathrm{TT}(\mathrm{N}=33)$ & \\
\hline & $\mathrm{BL}(\mathrm{cm})$ & $5.8966 \pm 0.09$ & $6.2900 \pm 0.17$ & $6.1091 \pm 0.12$ & 0.169 \\
\hline & $\mathrm{BW}(\mathrm{g})$ & $4.7759 \pm 0.19$ & $5.2800 \pm 0.51$ & $5.0364 \pm 0.28$ & 0.640 \\
\hline \multirow[t]{3}{*}{$2226 \mathrm{~A}>\mathrm{G}$} & & $\mathrm{AA}(\mathrm{N}=18)$ & $\mathrm{GA}(\mathrm{N}=35)$ & $\mathrm{GG}(\mathrm{N}=19)$ & \\
\hline & $\mathrm{BL}(\mathrm{cm})$ & $4.0532 \pm 0.16^{\mathrm{A}}$ & $4.3875 \pm 0.25^{\mathrm{A}}$ & $6.0314 \pm 0.15^{\mathrm{B}}$ & 0.008 \\
\hline & $\mathrm{BW}(\mathrm{g})$ & $3.9167 \pm 0.29^{\mathrm{a}}$ & $4.2886 \pm 0.17^{\mathrm{a}}$ & $5.8060 \pm 0.43^{\mathrm{b}}$ & 0.012 \\
\hline
\end{tabular}

BL: body length; BW: body weight. Values with different superscript letters within the same row differ significantly at $^{\mathrm{A}, \mathrm{B}} \mathrm{P}<0.01$ and ${ }^{\mathrm{a}, \mathrm{b}} \mathrm{P}<0.05$. 


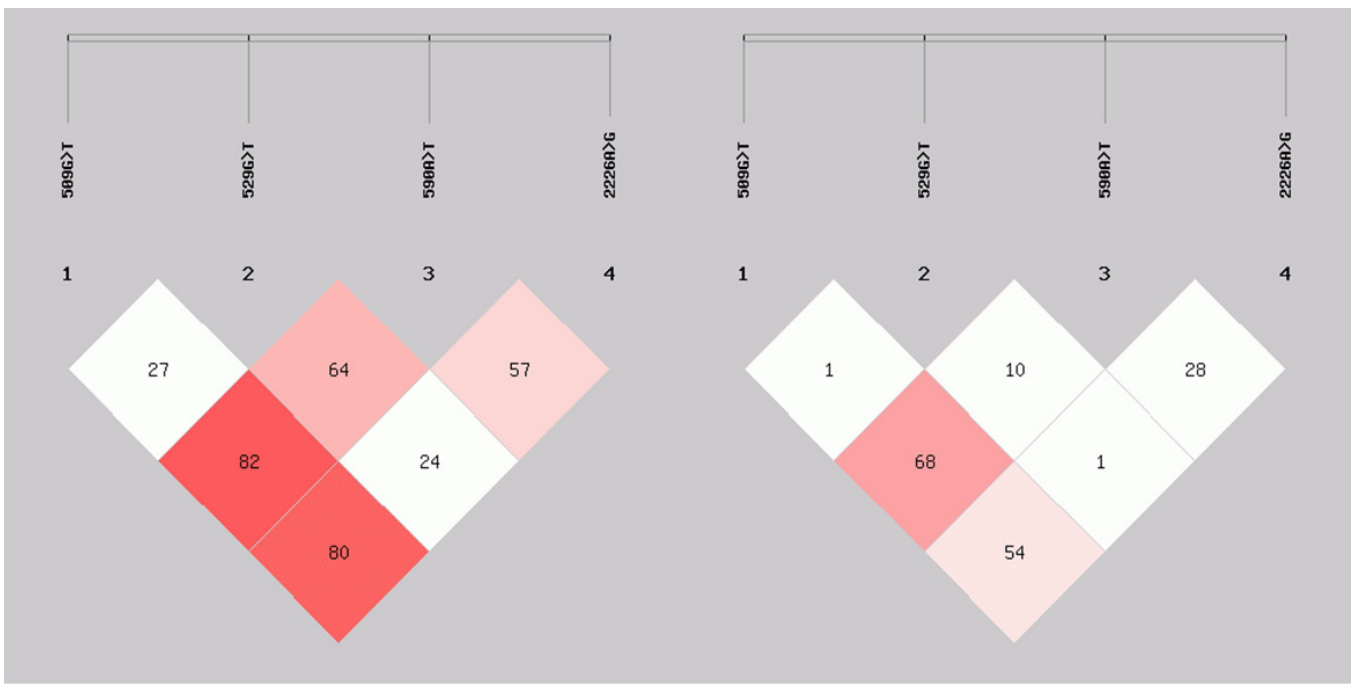

Figure. 3. Linkage disequilibrium (LD) plots of four IAG SNPs in this study using genotype data from a Macrobrachium nipponense population. Left figure shows $\mathrm{D}^{\prime}$ values of pairwise linkage disequilibrium analysis and the shading with a red-to-white gradient reflects higher to lower LD values (measured as D values). Right figure shows $r^{2}$ values of pairwise linkage disequilibrium analysis, the numbers were $r^{2}$ values (\%), and values within colored frames were above $33 \%$.

Table 4. Haplotype frequencies in the $I A G$ gene (haplotypes with frequency $<0.03$ have been ignored).

\begin{tabular}{lccccc}
\hline Haplotype & \multicolumn{2}{c}{ Position of sequence variant } & \multirow{2}{*}{ Frequency } \\
\cline { 2 - 5 } & $509 \mathrm{G}>\mathrm{T}$ & $529 \mathrm{G}>\mathrm{T}$ & $590 \mathrm{~A}>\mathrm{T}$ & $2226 \mathrm{~A}>\mathrm{G}$ & \\
\hline H1 & $\mathrm{G}$ & $\mathrm{G}$ & $\mathrm{A}$ & $\mathrm{A}$ & 0.3454 \\
H2 & $\mathrm{G}$ & $\mathrm{G}$ & $\mathrm{A}$ & $\mathrm{G}$ & 0.0454 \\
H3 & $\mathrm{G}$ & $\mathrm{T}$ & $\mathrm{T}$ & $\mathrm{G}$ & 0.0131 \\
H4 & $\mathrm{G}$ & $\mathrm{A}$ & $\mathrm{A}$ & 0.0178 \\
H5 & $\mathrm{T}$ & $\mathrm{A}$ & $\mathrm{G}$ & 0.4741 \\
H6 & $\mathrm{T}$ & $\mathrm{T}$ & $\mathrm{G}$ & 0.0266 \\
H7 & $\mathrm{G}$ & $\mathrm{G}$ & $\mathrm{A}$ & $\mathrm{A}$ & 0.0085 \\
H8 & $\mathrm{T}$ & $\mathrm{G}$ & $\mathrm{A}$ & $\mathrm{G}$ & 0.0052 \\
H9 & $\mathrm{T}$ & $\mathrm{G}$ & $\mathrm{T}$ & $\mathrm{A}$ & 0.0359 \\
H10 & $\mathrm{T}$ & $\mathrm{T}$ & $\mathrm{A}$ & $\mathrm{A}$ & 0.0134 \\
H11 & $\mathrm{T}$ & $\mathrm{G}$ & $\mathrm{T}$ & $\mathrm{G}$ & 0.0146 \\
\hline
\end{tabular}

\section{DISCUSSION}

Previous studies have confirmed that the androgenic gland plays multiple roles in sexual differentiation, masculinization, courtship behavior, and growth enhancement in crustaceans (Barki et al., 2003; Mareddy et al., 2011; Tropea et al., 2011). Further studies revealed that these phenomena were regulated by insulin-like peptide hormones encoded by the insulin superfamily gene (Ventura et al., 2009, 2011). $I A G$ is a member of the insulin superfamily, which has structural similarities to insulin-like growth factors, and which in turn have the potential to enhance growth in many organisms (Duan et al., 2010). Silencing of the $I A G$ gene in $M$. rosenbergii by dsRNA reduced the growth rate of male freshwater prawns (Ventura et 
al., 2009). This evidence suggests that the $I A G$ gene may be closely related to growth traits.

Owing to inconsistent reports about the tissue distribution of the IAG gene, we investigated the expression level of the $I A G$ gene in different tissues of $M$. nipponense. qRT-PCR showed that $I A G$ was present at low levels in the hepatopancreas, similar to results from C. sapidus (Chung et al., 2011) and F. chinensis (Ventura et al., 2012). However, this result also differed from a previous report (Ma et al., 2013). The distribution of the $I A G$ gene may be closely related to its biological function. Recently, in C. sapidus (Chung, 2014), the $I A G$ gene expressed specifically in the hepatopancreas is involved in the metabolism of carbohydrate. It is possible that the $I A G$ gene in the hepatopancreas is associated with growth traits in M. nipponense.

The $I A G$ genomic gene consisted of five exons and four introns, which differed from the $I A G$ gene in F. chinensis, which comprised four exons and three introns (Li et al., 2012). The four identified SNPs were genotyped using PCR-RFLP. No homozygous GG genotype was detected at the 509G>T loci. There are two possible explanations for this finding: 1) the frequency of the $\mathrm{G}$ allele may be low as a result of artificial selection, migration, and genetic drift, such that GG individuals are eliminated through natural selection; or 2) the sample size in this study may have been too small to detect GG individuals (Chang et al., 2012).

$H_{\mathrm{E}}, H_{\mathrm{O}}, N_{\mathrm{E}}$, and PIC were used as indices to evaluate the genetic variation in the population, where the higher the value of PIC, the greater the level of genetic variation. Moderate or high levels of polymorphism were detected at four loci in M. nipponense. This suggests that genetic polymorphisms are abundant, and may, thus, be suitable for linkage analysis between markers and traits.

The level of heterozygosity can reflect the degree of genetic uniformity. When heterozygosity is low, the degree of genetic uniformity is greater; when heterozygosity is $>0.5$, the group has not been intensely selected, and has abundant genetic diversity. The heterozygosity of the three loci ranged from 0.5417 to 0.7639 in the study, and can, thus, be further used in genetic selection. The 590A $>\mathrm{T}$ locus deviated from the Hardy-Weinberg equilibrium $(\mathrm{P}<$ $0.05, \chi^{2}$ test). It is possible that this locus maintained its dynamic unbalance through the action of factors, such as natural selection, reproductive isolation, migration, and/or genetic drift.

Haplotypes composed of SNPs provide greater power than single markers for analyzing genetic disease and trait associations because of the ancestral structures captured in the haplotype distributions (Akey et al., 2001). Notably, the power advantage for haplotype-based methods is the greatest when the marker alleles are not in strong LD with each other (Morris and Kaplan, 2002). $\mathrm{r}^{2}$ values $>0.33$ may indicate sufficiently strong LD to be useful for mapping (Ardlie et al., 2002). In this study, the SNP pairs 509G $>\mathrm{T} / 590 \mathrm{~A}>\mathrm{T}$ and $509 \mathrm{G}>\mathrm{T} / 2226 \mathrm{~A}>\mathrm{G}$ showed strong LD, though LD was low for other pairs (Figure 3). Haplotype analysis of the four SNPs using SHEsis identified 11 different haplotypes for $I A G$. Table 4 shows the 11 haplotypes with frequencies $>0.03$ (haplotypes with frequency $<0.03$ were ignored), of which H1 (GGAA) and H5 (GTAG) showed the highest haplotype frequency (34.54 and 47.41\%, respectively). High-frequency haplotypes have probably been present in the population for a long time. Consequently, most new mutants are derived from common haplotypes, implying that rare variants represent more recent mutations and are more likely to be related to common haplotypes than to other rare variants (Posada and Crandall, 2001). In this paper, the rare haplotypes $\mathrm{H} 7$ and $\mathrm{H} 8$, for example, may stem from common haplotypes $\mathrm{H} 1$ and $\mathrm{H} 5$.

Although the mechanisms whereby alternative genotypes in intronic SNPs affect growth traits are not understood, the important role of the non-coding portions of genomes has been widely acknowledged. Indeed, several studies have reported that introns are required not 
only for transcriptional regulation and mRNA stability, but also for the translation and stability of proteins (Beohar and Kawamoto, 1998; Surinya et al., 1998; Ghayor et al., 2000; Ozaki et al., 2002; Tokuhiro et al., 2003). Furthermore, non-coding RNAs transcribed from intronic regions are known to be involved in different biological processes, such as transcriptional and post-transcriptional control of gene expression (Nakaya et al., 2007). Mutations within introns could also affect both the splice donor and acceptor sites, or nearby regions and regulatory motifs within introns (Cheong et al., 2006). It is therefore possible that mutations within the intronic region of the $I A G$ gene may influence growth traits in M. nipponense.

Growth traits are affected by genetic, nutritional, and environmental factors. In this study, all prawns were reared under the same feeding and management conditions. Analysis of the associations between mutations and growth traits showed that locus $2226 \mathrm{~A}>\mathrm{G}$ had a significant effect on $\mathrm{BL}$ and $\mathrm{BW}$, whereas there were no significant differences between genotypes at the other three loci. Based on these results, individuals with better performance with the GG genotype at locus $2226 \mathrm{~A}>\mathrm{G}$ could be used to develop new breeds of $M$. nipponense, and this SNP could be used for molecular marker-assisted selection of growth traits.

We also amplified exons 1 and 2 and identified two SNPs in exon $2(1924 \mathrm{C}>\mathrm{G}$ and $2050 \mathrm{C}>\mathrm{A}$ ) with synonymous mutations, $\mathrm{ACC} / \mathrm{G} \rightarrow \mathrm{Thr}$ in $1924 \mathrm{C}>\mathrm{G}, \mathrm{CTG} / \mathrm{A} \rightarrow$ Leu in $2050 \mathrm{C}>\mathrm{A}$. The synonymous mutations may be related to the biological functions of the $I A G$ gene, as $I A G$ plays an important role in sexual differentiation, metabolism, and growth in crustaceans. The implementation of biological function depends on the conserved protein sequence. From an evolutionary standpoint, introns are, thus, under greater selection pressure than exons, and structural or sequence changes in introns may be responsible for functional gene changes in higher animals.

In conclusion, this study provides the first report of a genetic association between $I A G$ gene SNPs and growth traits in M. nipponense. These results strongly suggest that the GG genotype in $2226 \mathrm{~A}>\mathrm{G}$ could be used as a molecular marker for superior growth traits.

\section{ACKNOWLEDGMENTS}

Research supported by the National Natural Science Foundation of China (Grant \#31272654), the National Science \& Technology Supporting Program of the 12th Five-year Plan of China (\#2012BAD26B04), the Jiangsu Provincial Natural Science Foundation for Young Scholars of China (Grant \#BK2012091), the Science \& Technology Supporting Program of Jiangsu Province (Grant \#BE2012334), and the Freshwater Fisheries Research Center, China Central Governmental Research Institutional Basic Special Research Project from the Public Welfare Fund (\#2013JBFT07).

\section{REFERENCES}

Akey J, Jin L and Xiong M (2001). Haplotypes vs single marker linkage disequilibrium tests: what do we gain? Eur. J. Hum. Genet. 9: 291-300.

Ardlie KG, Kruglyak L and Seielstad M (2002). Patterns of linkage disequilibrium in the human genome. Nat. Rev. Genet. 3: 299-309.

Barki A, Karplus I, Khalaila I, Manor R, et al. (2003). Male-like behavioral patterns and physiological alterations induced by androgenic gland implantation in female crayfish. J. Exp. Biol. 206: 1791-1797.

Beohar N and Kawamoto S (1998). Transcriptional regulation of the human nonmuscle myosin II heavy chain-A gene. Identification of three clustered cis-elements in intron-1 which modulate transcription in a cell type- and differentiation state-dependent manner. J. Biol. Chem. 273: 9168-9178. 
Cai Y and Shokita S (2006). Report on a collection of freshwater shrimps (Crustacea: Decapoda: Caridea) from the Philippines, with descriptions of four new species. Raffles Bull. Zool. 54: 245-270.

Chang MT, Cheng YS and Huang MC (2012). A novel non-synonymous SNP of the COLX gene and its association with duck reproductive traits. Mol. Cell. Probes 26: 204-207.

Cheong H, Yoon DH, Kim LH, Park BL, et al. (2006). Growth hormone-releasing hormone (GHRH) polymorphisms associated with carcass traits of meat in Korean cattle. BMC Genet. 7: 35.

Chung JS (2014). An insulin-like growth factor found in hepatopancreas implicates carbohydrate metabolism of the blue crab Callinectes sapidus. Gen. Comp. Endocrinol. 199: 56-64.

Chung JS, Manor R and Sagi A (2011). Cloning of an insulin-like androgenic gland factor (IAG) from the blue crab, Callinectes sapidus: Implications for eyestalk regulation of IAG expression. Gen. Comp. Endocrinol. 173: 4-10.

Du X, Gan QF, Yuan ZR, Gao X, et al. (2012). Polymorphism of MyoD1 and Myf6 genes and associations with carcass and meat quality traits in beef cattle. Genet Mol. Res. 12: 6708-6717.

Duan C, Ren H and Gao S (2010). Insulin-like growth factors (IGFs), IGF receptors, and IGF-binding proteins: roles in skeletal muscle growth and differentiation. Gen. Comp. Endocrinol. 167: 344-351.

Fu CZ, Wang H, Mei CG, Wang JL, et al. (2013). SNPs at 3'-UTR of the bovine CDIPT gene associated with Qinchuan cattle meat quality traits. Genet. Mol. Res. 12: 775-782.

Ghayor C, Herrouin JF, Chadjichristos C, Ala-Kokko L, et al. (2000). Regulation of human COL2A1 gene expression in chondrocytes. Identification of C-Krox-responsive elements and modulation by phenotype alteration. J. Biol. Chem. 275: 27421-27438.

Hongtuo F, Sufei J and Yiwei X (2012). Current status and prospects of farming the giant river prawn (Macrobrachium rosenbergii) and the oriental river prawn (Macrobrachium nipponense) in China. Aquac. Res. 43: 993-998.

Li Z, Zhang Z, He Z, Tang W, et al. (2009). A partition-ligation-combination-subdivision EM algorithm for haplotype inference with multiallelic markers: update of the SHEsis (http://analysis.bio-X.cn). Cell Res. 19: 519-523.

Li S, Li F, Sun Z and Xiang J (2012). Two spliced variants of insulin-like androgenic gland hormone gene in the Chinese shrimp, Fenneropenaeus chinensis. Gen. Comp. Endocrinol. 177: 246-255.

Liu Y, Liu XL, He H and Gu YL (2012). Four SNPs of insulin-induced gene 1 associated with growth and carcass traits in Qinchuan cattle in China. Genet. Mol. Res. 11: 1209-1216.

Livak KJ and Schmittgen TD (2001). Analysis of relative gene expression data using real-time quantitative PCR and the $2^{-\triangle \Delta C}$ method. Methods 25: 402-408.

Ma KY, Lin JY, Guo SZ, Chen Y, et al. (2013). Molecular characterization and expression analysis of an insulin-like gene from the androgenic gland of the oriental river prawn, Macrobrachium nipponense. Gen. Comp. Endocrinol. 185: 90-96.

Manor R, Weil S, Oren S, Glazer L, et al. (2007). Insulin and gender: an insulin-like gene expressed exclusively in the androgenic gland of the male crayfish. Gen. Comp. Endocrinol. 150: 326-336.

Mareddy V, Rosen O, Thaggard H, Manor R, et al. (2011). Isolation and characterization of the complete cDNA sequence encoding a putative insulin-like peptide from the androgenic gland of Penaeus monodon. Aquaculture 318: 364-370.

Morris RW and Kaplan NL (2002). On the advantage of haplotype analysis in the presence of multiple disease susceptibility alleles. Genet. Epidemiol. 23: 221-233.

Nakaya HI, Amaral PP, Louro R, Lopes A, et al. (2007). Genome mapping and expression analyses of human intronic noncoding RNAs reveal tissue-specific patterns and enrichment in genes related to regulation of transcription. Genome Biol. 8: R43.

Ozaki K, Ohnishi Y, Iida A, Sekine A, et al. (2002). Functional SNPs in the lymphotoxin- $\alpha$ gene that are associated with susceptibility to myocardial infarction. Nat. Genet. 32: 650-654.

Posada D and Crandall KA (2001). Intraspecific gene genealogies: trees grafting into networks. Trends Ecol. Evol. 16: 37-45.

Rosen O, Manor R, Weil S, Gafni O, et al. (2010). A sexual shift induced by silencing of a single insulin-like gene in crayfish: ovarian upregulation and testicular degeneration. PLoS One 5: e15281.

Sroyraya M, Chotwiwatthanakun C, Stewart MJ, Soonklang N, et al. (2010). Bilateral eyestalk ablation of the blue swimmer crab, Portunus pelagicus, produces hypertrophy of the androgenic gland and an increase of cells producing insulin-like androgenic gland hormone. Tissue Cell 42: 293-300.

Surinya KH, Cox TC and May BK (1998). Identification and characterization of a conserved erythroid-specific enhancer located in intron 8 of the human 5-aminolevulinate synthase 2 gene. J. Biol. Chem. 273, 16798-16809.

Tokuhiro S, Yamada R, Chang X, Suzuki A, et al. (2003). An intronic SNP in a RUNX1 binding site of SLC22A4, encoding an organic cation transporter, is associated with rheumatoid arthritis. Nat. Genet. 35: 341-348.

Tropea C, Hermida GN and López Greco LS (2011). Effects of androgenic gland ablation on growth and reproductive parameters of Cherax quadricarinatus males (Parastacidae, Decapoda). Gen. Comp. Endocrinol. 174: 211-218.

Ventura T, Manor R, Aflalo ED, Weil S, et al. (2009). Temporal silencing of an androgenic gland-specific insulin-like gene affecting phenotypical gender differences and spermatogenesis. Endocrinology 150: 1278-1286.

Genetics and Molecular Research 14 (2): 5910-5921 (2015) 
Ventura T, Rosen O and Sagi A (2011). From the discovery of the crustacean androgenic gland to the insulin-like hormone in six decades. Gen. Comp. Endocrinol. 173: 381-388.

Ventura T, Manor R, Aflalo ED, Weil S, et al. (2012). Timing sexual differentiation: full functional sex reversal achieved through silencing of a single insulin-like gene in the prawn, Macrobrachium rosenbergii. Biol. Reprod. 86: 90.

Wang XP, Luoreng ZM, Li F, Wang JR, et al. (2012). Genetic polymorphisms of lipoprotein lipase gene and their associations with growth traits in Xiangxi cattle. Mol. Biol. Rep. 39: 10331-10338.

Yong Y and Lin H (2005). SHEsis, a powerful software platform for analyses of linkage disequilibrium, haplotype construction, and genetic association at polymorphism loci. Cell Res. 15: 97-98.

Zhang F, Chen L, Qin J, Zhao W, et al. (2011). cDNA cloning and expression analysis of gustavus gene in the oriental river prawn Macrobrachium nipponense. PLoS One 6: e17170. 